\title{
Effects of Paraquat-induced Oxidative Stress on the Neuronal Plasma Membrane $\mathrm{Ca}^{2+-A T P a s e}$
}

\author{
Asma Zaidi ${ }^{1,3}$, Denzyl Fernandes ${ }^{2}$, Jennifer L. Bean ${ }^{1}$, and Mary L. Michaelis ${ }^{1}$ \\ ${ }^{1}$ Department of Pharmacology and Toxicology, University of Kansas, Lawrence, KS 66045, USA \\ ${ }^{2}$ Genelogic Inc., 38 Sidney Street, Cambridge, MA 01239, USA
}

\section{Abstract}

Oxidative stress leads to the disruption of calcium homeostasis in brain neurons; however, the direct effects of oxidants on proteins that regulate intracellular calcium $\left[\mathrm{Ca}^{2+}\right]_{\mathrm{i}}$ are not known. The calmodulin $(\mathrm{CaM})$-stimulated plasma membrane $\mathrm{Ca}^{2+}$-ATPase (PMCA) plays a critical role in regulating $\left[\mathrm{Ca}^{2+}\right]_{\mathrm{i}}$. Our previous in vitro studies showed that PMCA present in brain synaptic membranes is readily inactivated by a variety of reactive oxygen species (ROS). The present studies were conducted to determine the vulnerability of PMCA to ROS generated in neurons as would likely occur in vivo. Primary cortical neurons were exposed to paraquat (PQ), a redox cycling agent that generates intracellular ROS. Low concentrations of PQ (5-10 $\mu \mathrm{M})$ increased PMCA basal activity by 2-fold but abolished its sensitivity to CaM. Higher concentrations (25-100 $\mu \mathrm{M})$ inhibited both components of PMCA activity. Immunoblots showed the formation of high molecular weight PMCA aggregates. Additionally, PMCA showed evidence of proteolytic degradation. PMCA proteolysis was prevented by a calpain inhibitor, suggesting a role for calpain. Our findings suggest that PMCA is a sensitive target of oxidative stress in primary neurons. Inactivation of this $\mathrm{Ca}^{2+}$ transporter under prolonged oxidative stress could alter neuronal $\mathrm{Ca}^{2+}$ signaling.

\section{Keywords}

PMCA; calmodulin; intracellular calcium; oxidative stress; paraquat; superoxide; hydrogen peroxide; calpain

\section{Introduction}

The plasma membrane $\mathrm{Ca}^{2+}$-ATPase (PMCA) pumps $\mathrm{Ca}^{2+}$ from the cytosol to the extracellular environment and plays a critical role in $\mathrm{Ca}^{2+}$ homeostasis. Together with the sarco-endoplasmic reticulum $\mathrm{Ca}^{2+}$-ATPase (SERCA) and the sodium calcium exchanger (NCX), the PMCA maintains precise levels of intracellular $\mathrm{Ca}^{2+}\left[\mathrm{Ca}^{2+}\right]_{\mathrm{i}}$ under resting conditions and following neuronal excitation [1,2]. PMCA activity is regulated by calmodulin $(\mathrm{CaM})$, a $16 \mathrm{kDa}$ protein known to serve as a universal $\mathrm{Ca}^{2+}$ sensor in all cells. In the absence of $\mathrm{CaM}$, the $\mathrm{C}$-terminal

\footnotetext{
(c) 2009 Elsevier Inc. All rights reserved.

Address for Correspondence: Asma Zaidi, Ph.D., Department of Biochemistry, Kansas City University of Medicine and Biosciences, 1750 Independence Avenue, Kansas City, MO 64106, Tel: 816-283-2297; Fax: 816-460-0553; Azaidi@kcumb.edu.

${ }^{3}$ Present Address: Department of Biochemistry, Kansas City University of Medicine and Biosciences, 1750 Independence Avenue, Kansas City, MO 64106, USA

Publisher's Disclaimer: This is a PDF file of an unedited manuscript that has been accepted for publication. As a service to our customers we are providing this early version of the manuscript. The manuscript will undergo copyediting, typesetting, and review of the resulting proof before it is published in its final citable form. Please note that during the production process errors may be discovered which could affect the content, and all legal disclaimers that apply to the journal pertain.
} 
autoinhibitory domain interacts with the catalytic site of PMCA thus inhibiting ATP hydrolysis and $\mathrm{Ca}^{2+}$ transport. As $\mathrm{Ca}^{2+}$ levels rise, binding of $\mathrm{Ca}^{2+} / \mathrm{CaM}$ to PMCA relieves autoinhibition and the pump is maximally activated [3-5]. Autoinhibition can also be relieved by the proteolytic cleavage of the $\mathrm{CaM}$ binding domain by proteases such as calpain and caspase, resulting in an irreversibly activated PMCA [6-8].

A close relationship has been established between loss of $\mathrm{Ca}^{2+}$ homeostasis and oxidative stress in brain neurons. Our previous studies on PMCA present in rat brain synaptic plasma membranes (SPMs) or purified from erythrocyte membranes showed that this enzyme is a sensitive target of free radical-induced oxidative damage and inactivation [9-11]. However, these studies were performed in vitro, in the absence of antioxidant defense systems normally present in intact cells to counteract and neutralize reactive oxygen species (ROS). The extent to which PMCA is vulnerable to oxidative stress in intact neurons is just beginning to be elucidated. Recent studies have shown that exposure of hippocampal neurons to exogenous hydrogen peroxide $\left(\mathrm{H}_{2} \mathrm{O}_{2}\right)$ and glutamate resulted in PMCA inactivation and degradation $[12,13]$. The effect of ROS generated in intact neurons through intracellular activation of the redox machinery as would likely occur in vivo is not known. The goal of the present studies was to determine the effects of the intracellular redox cycling agent paraquat $\left(1,1^{\prime}\right.$ - dimethyl $4,4^{\prime}$ - bipyridylium dichloride) (PQ) on the functional properties of PMCA in primary cortical neurons. Paraquat undergoes one-electron reduction by the flavoenzyme NADPH - cytochrome $\mathrm{P} 450$ reductase and is rapidly auto-oxidized in the presence of reducing equivalents, by donating its free electron to molecular oxygen, thereby generating superoxide free radicals $\left(\mathrm{O}_{2}{ }^{-}\right)$[14]. Superoxide can be further converted to $\mathrm{H}_{2} \mathrm{O}_{2}$ by the anti-oxidant enzyme superoxide dismutase (Mn-SOD and $\mathrm{Cu} / \mathrm{Zn}-\mathrm{SOD})$. The peroxide is converted to water and oxygen by glutathione peroxidase and catalase $[15,16]$.

Exposure of neurons to PQ resulted in nearly instantaneous generation of $\mathrm{O}_{2} \cdot{ }^{-}$, as monitored by the inactivation of aconitase, an enzyme with four iron-sulfur centers, believed to be one of the most sensitive targets of $\mathrm{O}_{2} \cdot{ }^{-}$[17]. Paraquat treatment led to a biphasic response in PMCA activity. Low concentrations of PQ stimulated basal PMCA activity and abolished its sensitivity to CaM, whereas higher concentrations inhibited both basal and CaM-stimulated PMCA activity. Functional changes were accompanied by formation of high molecular weight adducts of the PMCA protein. Additionally, evidence for PMCA proteolysis was indicated by the appearance of a faster moving band of PMCA. Proteolysis of the enzyme was prevented by pretreatment with a calpain inhibitor but not with a caspase inhibitor, suggesting a role for the $\mathrm{Ca}^{2+}$-activated protease calpain in the effects of PQ on the activity and structure of PMCA. Our results suggest that PMCA is a very sensitive target of oxidative stress in neurons.

Alterations in PMCA activity and structure under conditions of prolonged oxidative stress may contribute to altered $\mathrm{Ca}^{2+}$ homeostasis.

\section{Materials and Methods}

Ouabain, thapsigargin, oligomycin, ATP, 1, 2- bis (o-aminophenoxy) ethane-N,N, $\mathrm{N}^{\prime}, \mathrm{N}^{\prime}-$ tetraacetic acid acetoxy methyl ester (BAPTA-AM), calcein AM, and propidium iodide were purchased from Sigma Chemical Company (St. Louis, MO). The Protease Inhibitor Cocktail III, bovine brain CaM, calpain inhibitor (carbobenzoxy-valinyl-phenylalaninal) and pan caspase inhibitor (Ac-Asp-Glu-Val-Asp-chloromethylketone) were from Calbiochem (San Diego, CA). Bicinchoninic acid (BCA) protein assay kit was obtained from Pierce (Rockford, IL). The following sources were used for the various primary antibodies: Anti-pan PMCA, PMCA 2, PMCA 4, and anti-SERCA (Affinity Bioreagents Inc., Golden, CO), anti-cytochrome P450 reductase (Stressgen Inc., Victoria, Canada), anti- $\alpha$-fodrin (Chemicon, Temecula, CA), anti-calcineurin A and anti-neuronal nitric oxide synthase (nNOS) (Transduction Labs, Lexington, KY), and anti-NCX (Swant laboratories, Bellinzona, Switzerland). 


\section{Cell Culture}

Dissociated cortical neuron cultures were established from 18-day old Sprague Dawley fetuses as described previously [18-20]. Briefly, pups were delivered by cesarean section while the dam was fully anesthetized with pentobarbital $(0.1 \mathrm{~g} / \mathrm{kg})$, and the brains recovered according to protocols approved by the University of Kansas IACUC and in accordance with National Institutes of Health guidelines. The cortical lobes were dissected and cells dissociated by gentle trituration with trypsin. After the final precipitation step, neurons were resuspended in fresh DMEM/F-12 with $10 \%$ fetal calf serum (FCS), and plated at densities ranging from $0.3-3 \times$ $10^{6}$ cells/dish on $35 \mathrm{~mm}$ tissue culture dishes coated with poly-D-lysine. After $24 \mathrm{~h}$ to allow cell attachment, the FCS-containing medium was replaced by a defined medium with DMEM/ F12 containing $\mathrm{N}_{2}$ supplements, potassium bicarbonate $(15 \mathrm{mM})$, and $20 \%$ glial conditioned medium. Cells were fed twice a week by replacing $1 / 3$ of the medium with fresh medium. It was estimated that $>90 \%$ of the cells in the primary cultures were neurons, based on morphological characteristics and confirmation with immunofluorescent staining for glial fibrillary acidic protein and neuron specific enolase.

\section{Treatment of Neurons with Paraquat}

Primary cortical neurons were grown in culture for 6-7 days in vitro in a humidified atmosphere of $95 \%$ air $/ 5 \% \mathrm{CO}_{2}$ at $37^{\circ} \mathrm{C}$. Fresh stocks of PQ were made in water and sterile-filtered prior to treatment. Following addition of $15 \mu \mathrm{l}$ of a 100 -fold concentrated PQ stock solution to 1.5 $\mathrm{ml}$ of the culture medium, dishes were swirled gently to allow complete mixing of the drug with the medium and incubated at $37^{\circ} \mathrm{C}$ for the indicated periods of time.

\section{Determination of Aconitase Activity}

The activity of aconitase was measured by monitoring the conversion of isocitrate to cisaconitate, a product that can be measured at $240 \mathrm{~nm}[21,22]$. Control or PQ-treated neurons were lysed in a buffer containing $3 \mathrm{mM}$ Tris- $\mathrm{HCl}, \mathrm{pH} 7.5$, plus a cocktail of protease inhibitors $(5 \mu \mathrm{l} / \mathrm{ml})$, and centrifuged at $13,000 \times g$ for $15 \mathrm{~min}$ at $4^{\circ} \mathrm{C}$. Aliquots of the supernatant were added to the aconitase substrate buffer containing a final concentration of $25 \mathrm{mM}$ Tris- $\mathrm{HCl}$, $\mathrm{pH} 7.5,20 \mathrm{mM}$ isocitrate and $0.6 \mathrm{mM} \mathrm{MnCl} 2$, and the enzymatic activity was monitored for $15 \mathrm{~min}$ in a Varian UV-Vis spectrophotometer.

\section{Viability Assays}

The assays for neuronal viability were performed using calcein AM and propidium iodide labeling of live and dead neurons, respectively. Cells were incubated with calcein AM (150 $\mathrm{nM})$ and propidium iodide $(20 \mu \mathrm{M})$ added to the culture medium. After 30 min the media was removed, cells were rinsed with phosphate buffered saline, and visualized under a fluorescence microscope (Nikon Eclipse TE 200). Digital images were captured using Flashpoint software. The calcein AM - labeled viable cells (green) and the propidium iodide-labeled dead cells (red) were counted using the Adobe Image Ready program.

\section{Preparation of a Neuronal Particulate Fraction}

Following the indicated periods of exposure of the neuronal cultures to various concentrations of PQ, the culture medium was removed and cells washed twice with $200 \mathrm{mM}$ Tris- $\mathrm{HCl}, \mathrm{pH}$ 7.4. The neurons attached to the dish were scraped off and lysed in a buffer containing $3 \mathrm{mM}$ Tris- $\mathrm{HCl}, \mathrm{pH} 8.0$, plus the protease inhibitors $(5 \mu \mathrm{l} / \mathrm{ml})$. The neuronal lysate was centrifuged at $13,000 \times \mathrm{g}$ for $15 \mathrm{~min}$ at $4^{\circ} \mathrm{C}$ and the particulate fraction resuspended in a buffer containing $50 \mathrm{mM}$ Tris- $\mathrm{HCl}, \mathrm{pH} 7.4,0.32 \mathrm{M}$ sucrose and $50 \mu \mathrm{M} \mathrm{MgCl}_{2}$ plus protease inhibitors, and homogenized to form a uniform suspension. The protein concentration was determined by the BCA method following the manufacturer's instructions. 


\section{Determination of PMCA Activity}

The activity of PMCA was determined at $37^{\circ} \mathrm{C}$ as described previously [23]. The assay system contained the following in a volume of $100 \mu \mathrm{l}: 25 \mathrm{mM}$ Tris- $\mathrm{HCl}, \mathrm{pH} 7.4,50 \mathrm{mM} \mathrm{KCl}, 1 \mathrm{mM}$ $\mathrm{MgCl}_{2}, 4 \mu \mathrm{g}$ protein, $0.1 \mathrm{mM}$ ouabain, $100 \mathrm{nM}$ thapsigargin, $4 \mu \mathrm{g} / \mathrm{ml}$ oligomycin, $200 \mu \mathrm{M}$ EGTA, and the $\mathrm{CaCl}_{2}$ required to give a final free $\mathrm{Ca}^{2+}$ concentration of $0.5 \mu \mathrm{M}$. The free $\mathrm{Ca}^{2+}$ concentration was calculated using the software calcium.com that calculates the multiple equilibria between all ligands in solution. After a $5 \mathrm{~min}$ pre-incubation at $37^{\circ} \mathrm{C}$, the reaction was started by the addition of $1 \mathrm{mM}$ ATP, continued for $30 \mathrm{~min}$ at $37^{\circ} \mathrm{C}$, and stopped by addition of the Malachite Green dye solution [24]. The PMCA activity was defined as the $\mathrm{Ca}^{2+}$ activated ATP hydrolysis and expressed as nmoles of Pi liberated per mg of protein per min, based on values from a standard curve. The PMCA activity measured in the absence of CaM is referred to as 'basal activity' and that measured in presence of $340 \mathrm{nM} \mathrm{CaM}$ as 'CaMstimulated activity'.

\section{Immunoblot Analyses}

Neuronal proteins were separated by SDS-PAGE ( $7.5 \%$ gels) under non-reducing and reducing conditions (in presence of $3.3 \% \beta$ mercaptoethanol added to sample buffer) of electrophoresis and transferred to PVDF membranes as described previously [11]. Non-specific interactions were blocked with 5\% milk for $1 \mathrm{~h}$ at room temperature. The blots were incubated overnight with the indicated concentration of primary antibody. Alkaline phosphatase-conjugated secondary antibody (1:1000) was added for $2 \mathrm{~h}$ at room temperature. The reaction was developed using the substrate 5-bromo-4-chloro-3-indoyl phosphate and nitroblue tetrazolium. Blots were scanned using an HP Scanjet 4470, and relative intensities of the immunoreactive bands quantified using Adobe Photoshop 7.0.

\section{Data Analysis}

All data are means \pm SEM obtained from 3-5 experiments using independent cultures.

Statistical significance of differences between various samples was assessed using Student's $t$ test for unpaired samples and by single factor ANOVA.

\section{Results}

\section{Generation of Superoxide by Paraquat}

Although a definitive mechanism underlying PQ toxicity has not yet been delineated, it is widely acknowledged that a cyclic single electron reduction/oxidation of the parent molecule by cellular diaphorases is a critical mechanistic event [25]. Since the microsomal enzyme cytochrome $\mathrm{P} 450$ reductase is the most common cellular diaphorase known to be associated with the redox cycling of PQ [26], the first step was to confirm the presence of this enzyme in primary cortical neurons. Immunoblots probed with anti-cytochrome P-450 reductase antibody showed the appearance of a distinct band at $\sim 78 \mathrm{kDa}$, the expected size of the protein, thus confirming the presence of this enzyme in cortical neurons (Inset, Fig. 1).

The PQ radical formed as a consequence of redox cycling donates its electron to molecular $\mathrm{O}_{2}$, producing $\mathrm{O}_{2}{ }^{-}$radicals, believed to be the primary mediator of the biological toxicity of PQ [27]. The next step was to confirm PQ-mediated generation of $\mathrm{O}_{2}{ }^{-}$in cortical neurons. The enzyme aconitase is a major intracellular target of $\mathrm{O}_{2}{ }^{-}$, due to oxidant-mediated loss of a labile iron in its $4 \mathrm{~S} / 4 \mathrm{Fe}$ cluster $[17,28]$. Thus we monitored the inhibition of aconitase activity as a sensitive indicator of increasing $\mathrm{O}_{2} \cdot{ }^{-}$formation [21]. Control neuronal lysates showed robust aconitase activity $\left(8.4 \mathrm{U} / \mathrm{mg} / \mathrm{min}\right.$; slope $\left.=2.45 \times 10^{-3}\right)$, based on the time-dependent conversion of isocitrate to cis-aconitate, monitored spectrophotometrically at $240 \mathrm{~nm}$ (Fig. 1). Exposure of neurons to $50 \mu \mathrm{M} \mathrm{PQ}$ resulted in a time-dependent inhibition of aconitase activity; 
$\sim 23 \%$ inhibition was observed within $5 \mathrm{~min}\left(6.4 \mathrm{U} / \mathrm{mg} / \mathrm{min}\right.$; slope $\left.=1.88 \times 10^{-3}\right)$ and $\sim 89 \%$ after $15 \mathrm{~min}\left(1.0 \mathrm{U} / \mathrm{mg} / \mathrm{min}\right.$; slope $\left.=2.6 \times 10^{-4}\right)$, indicating an almost instantaneous generation of $\mathrm{O}_{2}{ }^{-}$in neurons exposed to $\mathrm{PQ}$. The aconitase activity was significantly diminished $(\sim 75 \%$ inhibition), after $24 \mathrm{~h}$ of exposure, suggesting a state of prolonged oxidative stress (ANOVA $F=24.4, \mathrm{~d} f=3, \mathrm{p}<0.001)$.

\section{Effects of Paraquat on Neuronal Viability}

The effects of PQ exposure on neuronal viability were determined by fluorescence microscopy. Control and PQ-treated cells were labeled with the dyes calcein AM and propidium iodide, visualized under a fluorescence microscope, and the percentage of surviving neurons estimated by counting the total number of calcein-labeled cells (live) and propidium iodide-labeled cells (dead) in multiple fields in each culture dish as described previously [19]. Control cultures exhibited a survival rate in excess of $85 \%$ at 7 days in vitro, consistent with our previous observations [19]. Neurons exposed to PQ $(5-100 \mu \mathrm{M})$ for $24 \mathrm{~h}$ showed a dose-dependent decrease in cell viability (Fig. 2). No statistically significant toxicity was observed with 5 or $10 \mu \mathrm{M} \mathrm{PQ}$, but the loss of cells was significant at concentrations of $25 \mu \mathrm{M}$ and higher, as determined by the Student's $t$ test $\left({ }^{*} \mathrm{p}<0.01\right.$ and $\left.* * \mathrm{p}<0.001\right)$. Cell viability at 25,50 , and 100 $\mu \mathrm{M} P Q$ was $80 \pm 4.2 \%, 60 \pm 8.2 \%$, and $36 \pm 8.5 \%$, respectively, compared to control cells, considered as $100 \%$.

\section{Effects of Paraquat on PMCA Activity}

Having established that exposure of neurons to PQ does indeed generate $\mathrm{O}_{2}{ }^{-}$giving rise to a prolonged state of oxidative stress and a significant decrease in cell viability, we determined the effects of this oxidative stress on PMCA activity. The enzyme activity was determined in the neuronal particulate fraction both in the absence and the presence of the PMCA activator $\mathrm{CaM}$. Thapsigargin was included in the assay to inhibit SERCA activity. Figure 3 shows PMCA activity in neurons exposed to increasing concentrations of PQ (5-100 $\mu \mathrm{M})$ for $24 \mathrm{~h}$. Basal PMCA activity in control neurons was $\sim 4 \mathrm{nmoles} \mathrm{Pi} / \mathrm{mg} / \mathrm{min}$. Addition of exogenous $\mathrm{CaM}$ $\left(340 \mathrm{nM}\right.$ ) led to a $\sim 2.5$ - fold stimulation in basal activity ( ${ }^{*} \mathrm{p}<0.05$ ), consistent with previous observations [3]. Exposure of neurons to $5 \mu \mathrm{M}$ PQ resulted in a significant increase in basal activity, which was $\sim 2$ - fold higher than in control cells ( $* * \mathrm{p}<0.01$ ). More interestingly, PMCA activity in $5 \mu \mathrm{M}$ PQ - treated samples was no longer sensitive to stimulation by CaM and did not exhibit any increase upon the addition of saturating concentrations of exogenous CaM. Exposure of neurons to $10 \mu \mathrm{M}$ and $25 \mu \mathrm{M}$ PQ also increased basal PMCA activity but abolished its sensitivity to $\mathrm{CaM}$, although the magnitude of the increase at these concentrations was lower compared with samples treated with $5 \mu \mathrm{M}$ PQ. In contrast, higher PQ concentrations (50 and $100 \mu \mathrm{M}$ ) caused a statistically significant inhibition of both basal and CaM-stimulated PMCA activity (\# p $<0.001$ ) suggesting the possibility of oxidative inactivation of the PMCA under these conditions.

\section{Effects of Paraquat on the Electrophoretic Mobility of PMCA}

The increase in basal activity and loss of CaM sensitivity observed at low PQ concentrations and inactivation of both components at higher concentrations might be indicative of structural modifications in the PMCA protein. We have previously shown that exposure of synaptic plasma membranes or purified PMCA to oxidants causes a shift in electrophoretic mobility due to the formation of high molecular weight aggregates [10,11]. Studies were conducted to determine if the PQ - induced effects on PMCA activity were correlated with structural changes in the protein. Control and PQ-treated samples were subjected to SDS-PAGE and immunoblot analysis with a pan antibody that recognizes all four known PMCA isoforms. In 7.5\% gels run under non-reducing conditions, the PMCA appeared as a somewhat diffuse band in the molecular mass range of $\sim 140 \mathrm{kDa}$, consistent with the presence of four different isoforms and 
their splice variants in brain neurons [29-31]. Exposure of neurons to increasing concentrations of PQ (5-100 $\mu \mathrm{M})$ for $24 \mathrm{~h}$ led to mobility shifts in PMCA migration (Fig. 4A). Under nonreducing conditions, the intensity of the $\sim 140 \mathrm{kDa}$ PMCA band decreased progressively with increasing PQ concentration (Fig. 4A, left panel). Densitometric analysis of immunoblots from 5 experiments revealed a 20\%, 28\%,44\%,46\%, and 56\% decrease in PMCA immunoreactivity at $5 \mu \mathrm{M}, 10 \mu \mathrm{M}, 25 \mu \mathrm{M}, 50 \mu \mathrm{M}$, and $100 \mu \mathrm{M} \mathrm{PQ}$, respectively. The loss of immunoreactivity of the PMCA monomer was accompanied by a concomitant increase in high molecular weight adducts that appeared at PQ concentrations of 50 and $100 \mu \mathrm{M}$.

When electrophoresis was performed in the presence of the reducing agent $\beta$-mercaptoethanol (3.3\%), the various PMCA isoforms were more clearly resolved, and four distinct bands were visible (Fig. 4A, right panel). The high molecular weight aggregates observed in the PQ-treated samples under non-reducing conditions disappeared, suggesting the contribution of cysteine oxidation in the formation of intermolecular PMCA adducts, consistent with our earlier in vitro oxidation studies $[10,11]$. More interestingly, PQ appeared to lead to PMCA cleavage, with the appearance of faster moving PMCA bands of smaller size (Fig. 4A, right panel).

PMCA proteolysis became significant at $25 \mu \mathrm{M}$ and higher as multiple PMCA bands became visible on the immunoblot and the four PMCA bands observed in control neurons collapsed into two distinct bands. Densitometric analysis of the multiple bands at $\sim 140 \mathrm{kDa}$, corresponding to the PMCA isoforms revealed a $10 \%$ decrease in immunoreactivity at 5 and $10 \mu \mathrm{M}$ PQ, 20\% decrease at $25 \mu \mathrm{M}$ PQ and a 50\% decrease at 50 and $100 \mu \mathrm{M}$ PQ.

To gain insight into the time-dependence of PMCA cleavage, we exposed neurons to PQ for time periods ranging from $2-24 \mathrm{~h}$. We selected a PQ concentration of $50 \mu \mathrm{M}$, i.e., a condition that yielded $\sim 50 \%$ decrease in immunoreactivity at $24 \mathrm{~h}$. Results showed that PMCA cleavage was initiated after $\sim 10-14 \mathrm{~h}$ of exposure of the neurons to PQ and increased progressively up to $24 \mathrm{~h}$ (Fig. 4B). Densitometric analysis of the immunoblot showed a $30 \%$ decrease at $10 \mathrm{~h}$, $40 \%$ at $14 \mathrm{~h}$, and a $50 \%$ decrease at 18 and $24 \mathrm{~h}$ of exposure to $50 \mu \mathrm{M} \mathrm{PQ}$.

From the generic profile of the pan antibody, it was unclear if individual PMCA isoforms were susceptible to proteolytic degradation induced by PQ. To determine the sensitivity of the 2 major PMCA subtypes, i.e., the brain specific isoform PMCA 2 and the house-keeping isoform PMCA 4, immunoblots of samples treated with $50 \mu \mathrm{M}$ PQ for $24 \mathrm{~h}$ were probed with antibodies to PMCA 2 and 4. The degradation pattern differed somewhat for the two isoforms (Fig. 5). Antibodies to PMCA 2 reacted with two distinct bands corresponding to its two splice variants ( 132 and $127 \mathrm{kDa}$ ) expressed in neurons [32]. On treatment with PQ, the two splice variants almost completely disappeared, and a new band with slightly faster mobility appeared. PMCA 4 antibodies reacted with two main bands in the control sample and PQ treatment produced a product of $\sim 124 \mathrm{kDa}$, consistent with previous observations on proteolytic cleavage of this isoform [6].

\section{Mechanism Underlying PQ-mediated PMCA Proteolysis}

In efforts to determine if other redox cycling agents have effects similar to PQ, we exposed neurons to duroquinone (DQ) $(5-100 \mu \mathrm{M}$ for $24 \mathrm{~h})$, another redox cycling agent that uses the cytochrome 450 reductase pathway to generate ROS. Treatment with DQ at concentrations of $25 \mu \mathrm{M}$ and higher led to PMCA proteolysis, suggesting that structural changes in this $\mathrm{Ca}^{2+}$ transporter were part of a response to redox cycling agents. Figure 6 shows the result of exposure of neurons to $50 \mu \mathrm{M}$ DQ for $24 \mathrm{~h}$. The cascade that accompanies redox cycling in cells involves depletion of cellular glutathione. To determine if glutathione depletion alone led to the proteolysis of PMCA, neurons were treated for $24 \mathrm{~h}$ with buthionine sulfoximine (100 $\mu \mathrm{M})$, an inhibitor of glutathione synthetase. Although this manipulation reduced GSH levels by $50 \%$, it did not influence the electrophoretic mobility of PMCA (Fig. 6A, lane 3), suggesting the proteolysis occurred in response to specific oxidant species. 
Although $\mathrm{O}_{2} \cdot{ }^{-}$is a relatively stable molecule capable of diffusing through the cell and attacking its target, it is ultimately dismutated by cellular SOD to form $\mathrm{H}_{2} \mathrm{O}_{2}[15,16]$. Additionally, $\mathrm{O}_{2}{ }^{--}$can react with nitric oxide to form the potent oxidant peroxynitrite [33]. Thus the $\mathrm{O}_{2}{ }^{-}$ resulting from PQ can lead to formation of other oxidants in neurons. To gain insight into the identity of the oxidant species responsible for the PQ-mediated PMCA proteolysis, we pretreated neurons with pharmacological agents capable of dismutating $\mathrm{O}_{2}{ }^{-}$to $\mathrm{H}_{2} \mathrm{O}_{2}$. Cell permeable manganese porphyrin compounds, capable of degrading $\mathrm{O}_{2}{ }^{-}$with very high rate constants $[34,35]$ were utilized to determine if $\mathrm{O}_{2}{ }^{-}$was likely responsible for the PMCA hydrolysis. Pretreatment of neurons with the SOD mimetics, Mn (III) tetrakis (1-methyl-4pyridyl) porphyrin pentachloride (MnTMPyP) $(100 \mu \mathrm{M})$ and Mn (III) tetrakis (4-benzoic acid) porphyrin chloride (MnTBAP) $(100 \mu \mathrm{M})$ for an hour prior to PQ exposure did not protect against PMCA proteolysis (Fig. 6A, lanes 5,6), suggesting that $\mathrm{O}_{2}{ }^{-}{ }^{-}$was not likely to be the active species. We examined the possibility that $\mathrm{ONOO}^{-}$, a potent oxidant formed by the reaction between $\mathrm{O}_{2}{ }^{-}$and nitric oxide, played a role in PMCA degradation. We employed two experimental manipulations. In the first, we pretreated neurons with nitro-L-arginine methyl ester (L-NAME), an inhibitor of nitric oxide synthase, an enzyme that generates nitric oxide and, in the second, we exposed neurons to morpholinosydnonimine (SIN-1) (10-100 $\mu \mathrm{M}$ for $24 \mathrm{~h}$ ), a compound that is a nitric oxide and $\mathrm{O}_{2}{ }^{-}$donor and thus a peroxynitrite generating system [36]. The results showed that these manipulations had no effect on PMCA mobility, indicating that peroxynitrite was not likely to lead to the proteolytic cleavage of PMCA in the intact cells with their complement of antioxidant systems (data not shown). Finally the possibility that the product of $\mathrm{O}_{2} \cdot{ }^{-}$dismutation by $\mathrm{SOD}$, i.e., $\mathrm{H}_{2} \mathrm{O}_{2}$, played a role in PMCA degradation was tested. Hydrogen peroxide $(50 \mu \mathrm{M})$ was added directly to the cell culture medium for $18 \mathrm{~h}$, taking advantage of its ability to cross the neuronal plasma membrane. Immunoblots revealed both degradation under reducing conditions of SDS-PAGE and PMCA aggregation under non-reducing conditions that matched very well with PQ-treated neurons (Fig.6B), suggesting that $\mathrm{H}_{2} \mathrm{O}_{2}$ is the oxidant species that most likely disrupts the PMCA activity and structure in the intact neurons.

\section{Role of Calpain in PMCA Proteolysis}

Oxidative stress results in the activation of several proteases, including calpain and caspase. PMCA is a substrate for the $\mathrm{Ca}^{2+}$-dependent protease calpain that cleaves it in the middle of the C-terminal CaM-binding domain, resulting in irreversible activation and lost sensitivity to $\mathrm{CaM}[6,37,38]$. More recently, PMCA has been shown to be cleaved by caspases, which, depending upon the treatment conditions, either activate or inhibit PMCA activity [7,8,39]. Both calpain and caspase generate PMCA proteolytic products that are quite similar in size (in the range of 127 and $120 \mathrm{kDa}$, respectively), making it difficult to identify the protease responsible for the proteolytic cleavage based on fragment profile alone $[7,8,39,40]$. In efforts to identity the protease family responsible for PMCA cleavage, we employed cell permeable inhibitors for both calpain and caspase. Neurons were pretreated for $1 \mathrm{~h}$ with either the calpain specific inhibitor carbobenzoxy-valinyl-phenylalaninal $(100 \mu \mathrm{M})$ or a pan caspase inhibitor Ac-Asp-Glu-Val-Asp-choromethyl ketone $(100 \mu \mathrm{M})$, prior to PQ $(50 \mu \mathrm{M})$ exposure for $24 \mathrm{~h}$. The results showed that the calpain inhibitor completely protected the PMCA against PQinduced proteolysis, but the caspase inhibitor had negligible effects under identical treatment conditions (Fig. 7A). To further confirm the contribution of calpain, a $\mathrm{Ca}^{2+}$-activated protease, we removed extracellular $\mathrm{Ca}^{2+}$ by changing to a $\mathrm{Ca}^{2+}$-free cell culture medium and simultaneously chelating intracellular $\mathrm{Ca}^{2+}$ by exposing neurons to the cell permeable $\mathrm{Ca}^{2+}$ chelating agent, 1, 2- bis (o-aminophenoxy) ethane- $N, \mathrm{~N}, \mathrm{~N}^{\prime}, \mathrm{N}^{\prime}$-tetraacetic acid acetoxy methyl ester (BAPTA-AM) $(50 \mu \mathrm{M})$ for 30 min prior to the addition of PQ. As shown in Fig. 7A, chelation of $\left[\mathrm{Ca}^{2+}\right]_{\mathrm{i}}$ by this manipulation protected PMCA from proteolysis, further indicating the contribution of the $\mathrm{Ca}^{2+}$-activated calpain. 


\section{Cleavage of other Known Calpain Substrates}

To determine if $\mathrm{PQ}$-induced PMCA proteolysis was unique to this $\mathrm{Ca}^{2+}$ transporter, we examined its effects on other $\mathrm{Ca}^{2+}$ transporters such as SERCA, an ATPase closely related to $\mathrm{PMCA}$, and the NCX. Exposure to $50 \mu \mathrm{M} \mathrm{PQ}$ for $24 \mathrm{~h}$ did not cause either the aggregation or proteolysis of SERCA or NCX, neither of which are regulated by CaM (Fig. 7B). It has been previously reported that activation of calpain under conditions of cellular stress, causes proteolytic degradation of a number of proteins possessing CaM binding domains [38,41-43]. To determine the susceptibility of other known calpain substrates to PQ, we examined the effects of PQ ( $50 \mu \mathrm{M}$ for $24 \mathrm{~h})$ on CaM - regulated proteins such as fodrin, CaN, and nNOS. The results of immunoblot analyses showed a decrease in the intact form of $\alpha$ - fodrin (240 $\mathrm{kDa})$, CaN A (60 kDa), and nNOS (155 kDa), concurrent with the appearance of smaller molecular weight fragments of these proteins (Fig. 7B). More interestingly, proteolytic degradation of these proteins was prevented by pretreatment of neurons with the calpain inhibitor carbobenzoxyvalinyl-phenylalaninal $(100 \mu \mathrm{M})$ but not the caspase inhibitor Ac-AspGlu-Val-Asp- choromethyl ketone $(100 \mu \mathrm{M})$, further suggesting the involvement of calpain in the PQ-mediated proteolysis of these proteins (data not shown).

\section{Discussion}

Exposure of primary cortical neurons to the redox cycling agent PQ led to functional and structural alterations in a critical $\mathrm{Ca}^{2+}$ regulating protein, the CaM-activated PMCA. The primary function of PMCA is to pump $\mathrm{Ca}^{2+}$ from the cytosol to the extracellular medium and balance the downhill influx of $\mathrm{Ca}^{2+}$ into cells. The four PMCA isoforms, and their splice variants thus coordinate the fine-tuning of low levels of $\left[\mathrm{Ca}^{2+}\right]_{\mathrm{i}}$, necessary for its second messenger function. Exposure of neurons to PQ resulted in a biphasic effect on basal PMCA activity. Lower PQ concentrations stimulated basal PMCA activity and abolished its sensitivity to CaM. This may be due to changes in the auto-inhibitory CaM-binding domain itself and/or in the regions of the PMCA active site that interact with it. It is possible that low concentrations of PQ may cause oxidative modification of critical residues which may in turn promote the dissociation of the CaM binding domain and hence a loss of sensitivity to CaM. Interestingly, of the twenty one cysteine residues in PMCA, ten are located in the intracellular active site domain between transmembrane segment 4 and 5. More interestingly, one of these residues, Cys 537, is present at the site of attachment of the autoinhibitory domain with the active site (residues 537-544)[9]. It is conceivable that oxidation of this and/or other residues may prevent the association of the CaM binding domain with the active site and hence a loss of autoinhibition and lost sensitivity to CaM. Dissociation of the autoinhibitory domain would also be expected to increase its accessibility to proteases and make the PMCA a better substrate for proteolytic degradation. Not surprisingly, at $25 \mu \mathrm{M} \mathrm{PQ}$, PMCA proteolysis was readily detected by the appearance of several new bands with faster mobility on SDS-PAGE. At higher concentrations (50 and $100 \mu \mathrm{M}$ ), the proteolysis was further evident as the four PMCA bands observed in control neurons collapsed into two distinct bands. The marked loss of PMCA activity at these PQ concentrations coincided with the formation of PMCA aggregates that appeared to be caused by oxidation of cysteine residues forming intermolecular disulfide bonds. The formation of PMCA aggregates is consistent with our in vitro observations that PMCA formed high molecular weight adducts and was inactivated upon exposure of SPMs to oxidants such as the peroxyl free radical generators 2,2'-Azobis 2 aminopropane dihydrochloride (AAPH) and 4,4'-Azobis 14-cyanovaleric acid (ACVA), peroxynitrite and $\mathrm{H}_{2} \mathrm{O}_{2}$ [11]. Similar results were obtained when purified PMCA was exposed to $\mathrm{H}_{2} \mathrm{O}_{2}$, suggesting that disulfide bondmediated protein aggregation is one mechanism for PMCA inactivation [10].

The primary mediator of the biological toxicity of PQ is widely acknowledged to be $\mathrm{O}_{2}{ }^{-}$ [27]. Our results showed that $\mathrm{O}_{2}{ }^{-}$was generated within 5 min of exposing neurons to PQ, 
based on the inactivation of aconitase. However, no obvious changes in PMCA activity or structure were evident within this short time frame. In fact, the earliest time point showing PMCA proteolysis was after 10 hours of incubation with PQ. These findings suggest that $\mathrm{O}_{2}{ }^{-}$may not directly mediate PQ-induced PMCA proteolysis, a hypothesis that was further substantiated by the lack of protection against PMCA degradation by SOD mimetics. In fact, addition of $\mathrm{H}_{2} \mathrm{O}_{2}$ to the culture medium replicated the effect of $P Q$, suggesting that $\mathrm{H}_{2} \mathrm{O}_{2}$, a downstream oxidant formed by dismutation of $\mathrm{O}_{2}{ }^{-}$, may play a role in PMCA proteolysis and aggregation. These results are consistent with recent studies showing degradation of PMCA in hippocampal neurons exposed to $\mathrm{H}_{2} \mathrm{O}_{2}$ [12].

Among the proteases likely to hydrolyze PMCA, calpain and caspase have been shown to cleave the enzyme near the CaM binding domain [6-8,38,39]. Our investigation into the mechanism underlying PQ-mediated PMCA proteolysis indicated that calpain was the predominant mediator of cleavage in the neurons. The strongest evidence supporting a specific role for calpain and not caspase was the abrogation of PMCA proteolysis by pretreatment of neurons with a cell permeable calpain-specific inhibitor but not a caspase inhibitor. Secondly, PMCA proteolysis was abolished by chelation of $\left[\mathrm{Ca}^{2+}\right]_{i}$, a specific requirement for calpain but not caspase, [41,44-46]. Thirdly, other known calpain substrates such as $\alpha$-fodrin, CaN A, and nNOS also showed evidence of proteolysis, an effect that was blocked by exposure of cells to the calpain inhibitor. Our results also indicated that oxidative stress targeted the proteolysis of PMCA 2 and PMCA 4 isoforms, despite substantial differences in their $\mathrm{C}$ terminal region near the CaM binding domain, the site of calpain cleavage [6]. It is conceivable that cells with the slower PMCA 4 might benefit from the proteolysis of the pump to a faster form. The calpainmediated cleavage of the CaM binding domain and resultant PMCA activation under conditions of mild oxidative stress may be a defense mechanism employed to counteract $\mathrm{Ca}^{2+}$ overload and maintain cell viability [38]. However, prolonged and/or severe oxidative stress such as that occurring at high PQ concentrations or under pathophysiological conditions such as stroke may result in protein oxidative modification and subsequent inactivation of the PMCA. Notably, SERCA and NCX, two other $\mathrm{Ca}^{2+}$ transporters remained remarkably intact even at the highest PQ concentration used, suggesting that the cleavage of PMCA is specific, rather than part of a general proteolytic phenomenon.

Our results are in close agreement with recent studies demonstrating a calpain- mediated internalization of PMCA 2 and 4 in response to glutamate [13] and $\mathrm{H}_{2} \mathrm{O}_{2}$ [12]. Given that oxidative modifications would make the PMCA protein more hydrophilic $[9,10]$, it is possible that oxidation makes the PMCA more susceptible to cleavage by exposing calpain-sensitive sites on the protein. Thus calpain may play an active role in the internalization and clearance of oxidatively modified PMCA. These observations may have implications in brain aging where we have observed a progressive decline in the activity and protein levels of the PMCA in synaptic membranes isolated from rat brain [23]. Given the chronic conditions of elevated oxidative stress reported to exist in the aging brain, it is possible that the PMCA in aged neurons may be oxidatively modified and consequently removed from the membranes by the action of calpain and/or other components of the cellular degradation machinery.

Despite the slight differences in cleavage-site specificity, an increasing number of cellular proteins including spectrin, tau, CaM-dependent protein kinases, CaN, and the PMCA are found to be susceptible to both calpain and caspase $[38,41,42,47,48]$. The unique susceptibility of these substrates to both proteases may depend on the stressor stimulus and the cell type. Calpains cleave a relatively small fraction of the cellular proteome, but most proteins in this list are those possessing CaM binding domains, as observed in several laboratories [43,49, 50]. Our observations support this contention by demonstrating the calpain -mediated cleavage of $\mathrm{CaM}$ binding proteins such as $\alpha$-fodrin, $\mathrm{CaN}$, and nNOS, proteins that play a crucial role in $\mathrm{Ca}^{2+}$-dependent signal transduction pathways. 
In conclusion, we propose that cleavage of PMCA and the other CaM-binding proteins by calpain may not only modulate the intensity and duration of the $\mathrm{Ca}^{2+}$ signal but, at the same time, render a CaM pool available for other cellular functions, capable of influencing stressinduced cellular responses. Our observations indicate that mild oxidative stress favored PMCA activation that correlated well with cell survival, in sharp contrast to strong conditions of oxidative stress that coincided with the inactivation of PMCA and cell demise. PMCA can therefore be viewed not only as a $\mathrm{Ca}^{2+}$ transporting protein the sole function of which is to maintain $\left[\mathrm{Ca}^{2+}\right]_{i}$ levels, but also as a very precisely-controlled regulator of important $\mathrm{Ca}^{2+}$ dependent signal transduction pathways that promote cell survival and/or cell death.

\section{Acknowledgments}

This research was supported by AG12993 and RR-P20 17708

\section{Abbreviations}

PMCA, plasma membrane $\mathrm{Ca}^{2+}$ - ATPase; CaM, calmodulin; PQ, paraquat; ROS, reactive oxygen species.

\section{References}

1. Blaustein MP. Calcium transport and buffering in neurons. Trends Neurosci 1988;11:438-443. [PubMed: 2469161]

2. Miller RJ. The control of neuronal Ca2+ homeostasis. Prog Neurobiol 1991;37:255-285. [PubMed: 1947178]

3. Carafoli E, Brini M. Calcium pumps: structural basis for and mechanism of calcium transmembrane transport. Curr Opin Chem Biol 2000;4:152-161. [PubMed: 10742184]

4. Carafoli E, Stauffer T. The plasma membrane calcium pump: functional domains, regulation of the activity, and tissue specificity of isoform expression. J Neurobiol 1994;25:312-324. [PubMed: 8195792]

5. Pottorf WJ, Thayer SA. Transient rise in intracellular calcium produces a long-lasting increase in plasma membrane calcium pump activity in rat sensory neurons. J Neurochem 2002;83:1002-1008. [PubMed: 12421373]

6. James P, Vorherr T, Krebs J, Morelli A, Castello G, McCormick DJ, Penniston JT, De Flora A, Carafoli E. Modulation of erythrocyte Ca2+-ATPase by selective calpain cleavage of the calmodulin-binding domain. J Biol Chem 1989;264:8289-8296. [PubMed: 2542272]

7. Paszty K, Antalffy G, Penheiter AR, Homolya L, Padanyi R, Ilias A, Filoteo AG, Penniston JT, Enyedi A. The caspase-3 cleavage product of the plasma membrane Ca2+-ATPase $4 \mathrm{~b}$ is activated and appropriately targeted. Biochem J 2005;391:687-692. [PubMed: 16080782]

8. Paszty K, Verma AK, Padanyi R, Filoteo AG, Penniston JT, Enyedi A. Plasma membrane Ca2+ATPase isoform $4 \mathrm{~b}$ is cleaved and activated by caspase- 3 during the early phase of apoptosis. J Biol Chem 2002;277:6822-6829. [PubMed: 11751908]

9. Lushington GH, Zaidi A, Michaelis ML. Theoretically predicted structures of plasma membrane Ca (2+)-ATPase and their susceptibilities to oxidation. J Mol Graph Model 2005;24:175-185. [PubMed: 16169758]

10. Zaidi A, Barron L, Sharov VS, Schoneich C, Michaelis EK, Michaelis ML. Oxidative inactivation of purified plasma membrane Ca2+-ATPase by hydrogen peroxide and protection by calmodulin. Biochemistry 2003;42:12001-12010. [PubMed: 14556631]

11. Zaidi A, Michaelis ML. Effects of reactive oxygen species on brain synaptic plasma membrane Ca (2+)-ATPase. Free Radic Biol Med 1999;27:810-821. [PubMed: 10515585]

12. Kip SN, Strehler EE. Rapid downregulation of NCX and PMCA in hippocampal neurons following H2O2 oxidative stress. Ann N Y Acad Sci 2007;1099:436-439. [PubMed: 17446483] 
13. Pottorf WJ 2nd, Johanns TM, Derrington SM, Strehler EE, Enyedi A, Thayer SA. Glutamate-induced protease-mediated loss of plasma membrane $\mathrm{Ca} 2+$ pump activity in rat hippocampal neurons. $\mathbf{J}$ Neurochem 2006;98:1646-1656. [PubMed: 16923173]

14. Smith P, Heath D. Paraquat. CRC Crit Rev Toxicol 1976;4:411-445. [PubMed: 791582]

15. Halliwell B, Gutteridge JM. Free radicals and antioxidant protection: mechanisms and significance in toxicology and disease. Hum Toxicol 1988;7:7-13. [PubMed: 3278973]

16. Sies H. Oxidative stress: from basic research to clinical application. Am J Med 1991;91:31S-38S. [PubMed: 1928209]

17. Patel M, Day BJ, Crapo JD, Fridovich I, McNamara JO. Requirement for superoxide in excitotoxic cell death. Neuron 1996;16:345-355. [PubMed: 8789949]

18. Michaelis ML, Ansar S, Chen Y, Reiff ER, Seyb KI, Himes RH, Audus KL, Georg GI. \{beta\}Amyloid-induced neurodegeneration and protection by structurally diverse microtubule-stabilizing agents. J. Pharmacol Exp Ther 2005;312:659-668. [PubMed: 15375176]

19. Michaelis ML, Ranciat N, Chen Y, Bechtel M, Ragan R, Hepperle M, Liu Y, Georg G. Protection against beta-amyloid toxicity in primary neurons by paclitaxel (Taxol). J Neurochem 1998;70:16231627. [PubMed: 9523579]

20. Michaelis ML, Walsh JL, Pal R, Hurlbert M, Hoel G, Bland K, Foye J, Kwong WH. Immunologic localization and kinetic characterization of a $\mathrm{Na}+/ \mathrm{Ca} 2+$ exchanger in neuronal and non-neuronal cells. Brain Res 1994;661:104-116. [PubMed: 7834362]

21. Gardner PR, Fridovich I. Inactivation-reactivation of aconitase in Escherichia coli. A sensitive measure of superoxide radical. J Biol Chem 1992;267:8757-8763. [PubMed: 1315737]

22. Gardner PR, Raineri I, Epstein LB, White CW. Superoxide radical and iron modulate aconitase activity in mammalian cells. J Biol Chem 1995;270:13399-13405. [PubMed: 7768942]

23. Zaidi A, Gao J, Squier TC, Michaelis ML. Age-related decrease in brain synaptic membrane Ca2+ATPase in F344/BNF1 rats. Neurobiol Aging 1998;19:487-495. [PubMed: 9880051]

24. Lanzetta PA, Alvarez LJ, Reinach PS, Candia OA. An improved assay for nanomole amounts of inorganic phosphate. Anal Biochem 1979;100:95-97. [PubMed: 161695]

25. Bus JS, Gibson JE. Paraquat: model for oxidant-initiated toxicity. Environ Health Perspect 1984;55:37-46. [PubMed: 6329674]

26. Ghersi-Egea JF, Perrin R, Leininger-Muller B, Grassiot MC, Jeandel C, Floquet J, Cuny G, Siest G, Minn A. Subcellular localization of cytochrome P450, and activities of several enzymes responsible for drug metabolism in the human brain. Biochem Pharmacol 1993;45:647-658. [PubMed: 8442765]

27. Krall J, Bagley AC, Mullenbach GT, Hallewell RA, Lynch RE. Superoxide mediates the toxicity of paraquat for cultured mammalian cells. J Biol Chem 1988;263:1910-1914. [PubMed: 2828357]

28. Hausladen A, Fridovich I. Superoxide and peroxynitrite inactivate aconitases, but nitric oxide does not. J Biol Chem 1994;269:29405-29408. [PubMed: 7961919]

29. Filoteo AG, Elwess NL, Enyedi A, Caride A, Aung HH, Penniston JT. Plasma membrane Ca2+ pump in rat brain. Patterns of alternative splices seen by isoform-specific antibodies. J Biol Chem 1997;272:23741-23747. [PubMed: 9295318]

30. Stauffer TP, Hilfiker H, Carafoli E, Strehler EE. Quantitative analysis of alternative splicing options of human plasma membrane calcium pump genes. J. Biol. Chem 1994;269:32022. [PubMed: 7989379]

31. Stauffer TP, Guerini D, Carafoli E. Tissue distribution of the four gene products of the plasma membrane Ca2+ pump. A study using specific antibodies. J Biol Chem 1995;270:12184-12190. [PubMed: 7538133]

32. Guerini D, Garcia-Martin E, Gerber A, Volbracht C, Leist M, Merino CG, Carafoli E. The expression of plasma membrane $\mathrm{Ca} 2+$ pump isoforms in cerebellar granule neurons is modulated by $\mathrm{Ca} 2+\mathrm{J}$. Biol. Chem 1999;274:1667-1676. [PubMed: 9880546]

33. Koppenol WH, Moreno JJ, Pryor WA, Ischiropoulos H, Beckman JS. Peroxynitrite, a cloaked oxidant formed by nitric oxide and superoxide. Chem. Res. Toxicol 1992;5:834-842. [PubMed: 1336991]

34. Faulkner KM, Liochev SI, Fridovich I. Stable Mn(III) porphyrins mimic superoxide dismutase in vitro and substitute for it in vivo. J. Biol. Chem 1994;269:23471-23476. [PubMed: 8089112] 
35. Faulkner KM, Stevens RD, Fridovich I. Characterization of Mn(III) complexes of linear and cyclic desferrioxamines as mimics of superoxide dismutase activity. Arch. Biochem. Biophys 1994;310:341-346. [PubMed: 8179317]

36. Gow AJ, Chen Q, Gole M, Themistocleous M, Lee VM, Ischiropoulos H. Two distinct mechanisms of nitric oxide-mediated neuronal cell death show thiol dependency. Am. J. Physiol. Cell Physiol 2000;278:C1099-1107. [PubMed: 10837337]

37. Papp B, Sarkadi B, Enyedi A, Caride AJ, Penniston JT, Gardos G. Functional domains of the in situ red cell membrane calcium pump revealed by proteolysis and monoclonal antibodies. Possible sites for regulation by calpain and acidic lipids. J. Biol. Chem 1989;264:4577-4582. [PubMed: 2538449]

38. Wang KK, Villalobo A, Roufogalis BD. Activation of the Ca2+-ATPase of human erythrocyte membrane by an endogenous Ca2+-dependent neutral protease. Arch. Biochem. Biophys 1988;260:696-704. [PubMed: 2829740]

39. Schwab BL, Guerini D, Didszun C, Bano D, Ferrando-May E, Fava E, Tam J, Xu D, Xanthoudakis S, Nicholson DW, Carafoli E, Nicotera P. Cleavage of plasma membrane calcium pumps by caspases: a link between apoptosis and necrosis. Cell Death Differ 2002;9:818-831. [PubMed: 12107825]

40. Molinari M, Anagli J, Carafoli E. Ca(2+)-activated neutral protease is active in the erythrocyte membrane in its nonautolyzed 80-kDa form. J. Biol. Chem 1994;269:27992-27995. [PubMed: 7961733]

41. Hajimohammadreza I, Raser KJ, Nath R, Nadimpalli R, Scott M, Wang KK. Neuronal nitric oxide synthase and calmodulin-dependent protein kinase IIalpha undergo neurotoxin-induced proteolysis. J. Neurochem 1997;69:1006-1013. [PubMed: 9282922]

42. Wang KK, Roufogalis BD, Villalobo A. Characterization of the fragmented forms of calcineurin produced by calpain I. Biochem. Cell Biol 1989;67:703-711. [PubMed: 2556162]

43. Wang KK, Villalobo A, Roufogalis BD. Calmodulin-binding proteins as calpain substrates. Biochem. J 1989;262:693-706. [PubMed: 2556106]

44. Boivin P, Galand C, Dhermy D. In vitro digestion of spectrin, protein 4.1 and ankyrin by erythrocyte calcium dependent neutral protease (calpain I). Int. J. Biochem 1990;22:1479-1489. [PubMed: 2148914]

45. Seubert P, Baudry M, Dudek S, Lynch G. Calmodulin stimulates the degradation of brain spectrin by calpain. Synapse 1987;1:20-24. [PubMed: 2850618]

46. Siman R, Baudry M, Lynch G. Brain fodrin: substrate for calpain I, an endogenous calcium-activated protease. Proc. Natl. Acad. Sci., U. S. A 1984;81:3572-3576. [PubMed: 6328521]

47. Aki T, Yoshida K, Fujimiya T. Phosphoinositide 3-kinase accelerates calpain-dependent proteolysis of fodrin during hypoxic cell death. J. Biochem. (Tokyo) 2002;132:921-926. [PubMed: 12473194]

48. Xie H, Johnson GV. Ceramide selectively decreases tau levels in differentiated PC12 cells through modulation of calpain I. J. Neurochem 1997;69:1020-1030. [PubMed: 9282924]

49. Kosaki G, Tsujinaka T, Kambayashi J, Morimoto K, Yamamoto K, Yamagami K, Sobue K, Kakiuchi $\mathrm{S}$. Specific cleavage of calmodulin-binding proteins by low $\mathrm{Ca} 2+$-requiring form of $\mathrm{Ca} 2+$-activated neutral protease in human platelets. Biochem. Int 1983;6:767-775. [PubMed: 6091657]

50. Wallace RW, Tallant EA, McManus MC. Human platelet calmodulin-binding proteins: identification and Ca2+-dependent proteolysis upon platelet activation. Biochemistry 1987;26:2766-2773. [PubMed: 3111525] 


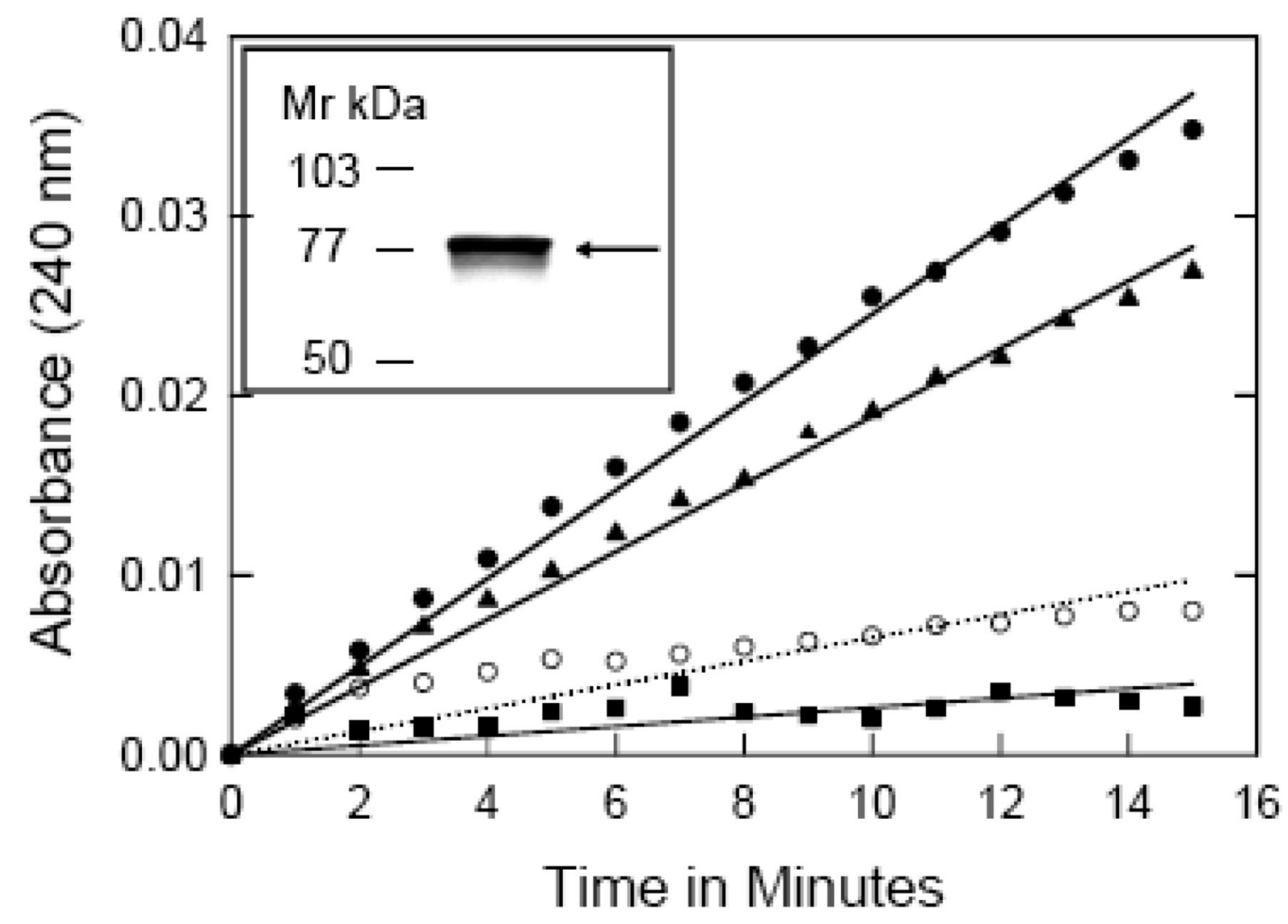

Fig. 1.

Effect of PQ on the activity of aconitase. Control cortical neurons ( $\bullet$ ) or those exposed to 50 $\mu \mathrm{M}$ PQ for $5 \mathrm{~min}(\boldsymbol{\Delta}), 15 \mathrm{~min}(\boldsymbol{\bullet})$, and $24 \mathrm{~h}$ (o, dotted line) were lysed with $3 \mathrm{mM}$ Tris- $\mathrm{HCl}$, $\mathrm{pH} 7.5$, plus a protease inhibitor cocktail $(5 \mu \mathrm{l} / \mathrm{ml})$ and centrifuged at $13,000 \times \mathrm{g}$ for $15 \mathrm{~min}$ at $4{ }^{\circ} \mathrm{C}$. The supernatant was assayed for aconitase activity by monitoring the formation of cisaconitate from isocitrate at $240 \mathrm{~nm}$ as described under 'Methods'. Statistical significance was determined by single factor $\operatorname{ANOVA}(F=24.4, \mathrm{~d} f=3, \mathrm{p}<0.001)$. The inset shows cytochrome $\mathrm{P} 450$ reductase immunoreactivity in neuronal lysate. Briefly, $50 \mu \mathrm{g}$ protein from neuronal lysate was separated on a 10\% SDS-PAGE, transferred to a PVDF membrane, and probed with anti-cytochrome $\mathrm{P} 450$ reductase antibody (1:1000) and an alkaline phosphataselabeled secondary antibody (1:1000) for 2 hours. Color was developed by NBT and BCIP as described under methods. A distinct band corresponding to $\sim 78 \mathrm{kDa}$, the expected size for cytochrome $\mathrm{P} 450$ reductase, was visible on the immunoblot. 


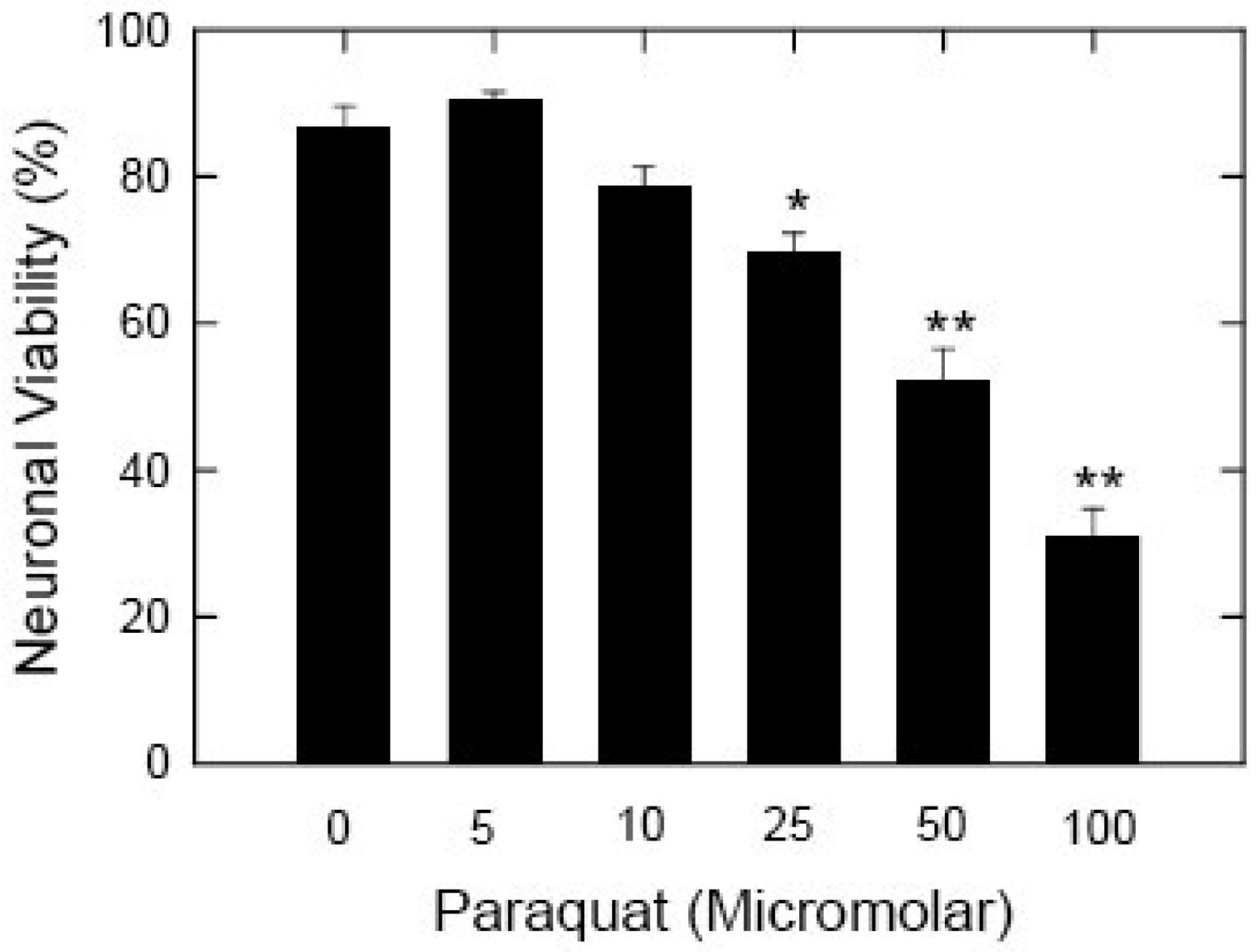

Fig. 2.

Effects of increasing concentrations of PQ on neuronal viability. Primary cortical neurons plated at a density of 300,000 on $35 \mathrm{~mm}$ cut-out glass coverslip dishes were exposed to PQ for $24 \mathrm{~h}$ at a final concentration of $0,5,10,25,50$ and $100 \mu \mathrm{M}$. Neurons were labeled with the dyes calcein AM and propidium iodide and the fluorescence images captured on a fluorescence microscope (Nikon Eclipse TE 200). The green (live) and red (dead) cells were counted and data expressed as the percent of total cells in each field that were viable. Data points represent means \pm S.E.M. of quadruplicate determinations at each condition in 10 experiments using different cultures. Statistical significance was determined by Student $t$ test $(* \mathrm{p}<0.01$ and ** $\mathrm{p}<0.001$ ). 


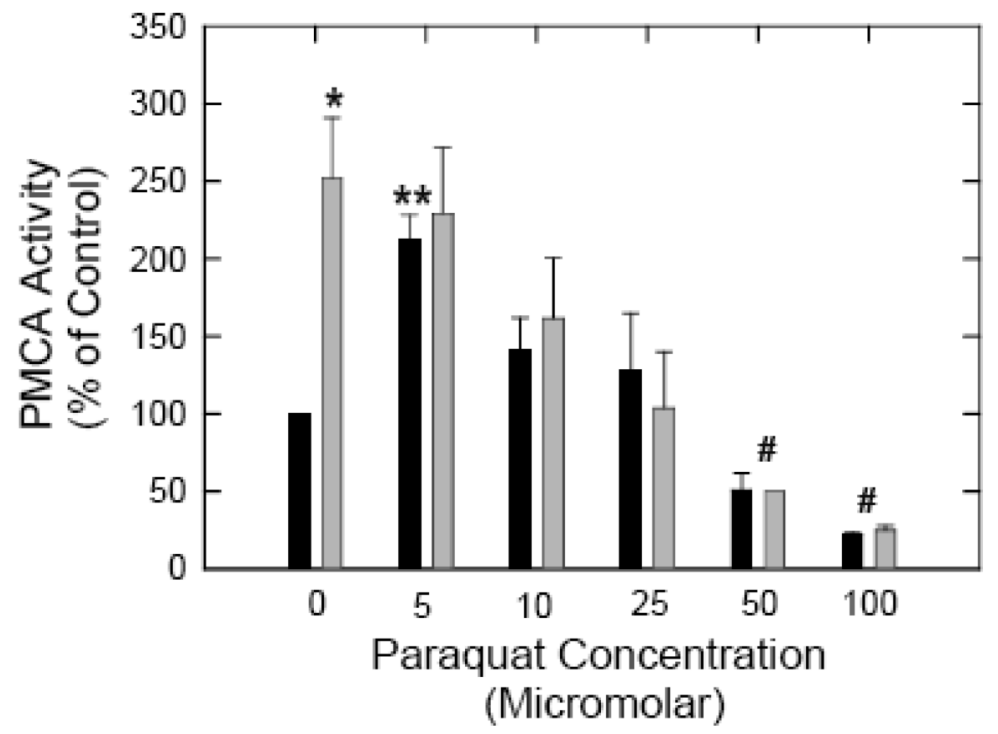

Fig. 3.

Effects of increasing concentrations of PQ on PMCA activity. Cortical neurons were exposed to the indicated concentrations of PQ for $24 \mathrm{~h}$ and lysed in $3 \mathrm{mM}$ Tris- $\mathrm{HCl} \mathrm{pH} 8.0$ with protease inhibitors $(5 \mu \mathrm{l} / \mathrm{ml})$. The particulate fraction obtained after centrifugation at $13,000 \times \mathrm{g}$ for 15 min was resuspended in $50 \mathrm{mM}$ Tris- $\mathrm{Cl}, \mathrm{pH} 7.4,0.32 \mathrm{M}$ sucrose and $50 \mu \mathrm{M} \mathrm{MgCl}_{2}$. PMCA activity was measured in the absence (black bars) and presence (grey bars) of $340 \mathrm{nM}$ bovine brain $\mathrm{CaM}$ as described under 'Methods'. Data points represent means \pm S.E.M. of triplicate determinations across 5 experiments using independent cultures. Statistical significance of the stimulation of PMCA basal activity by CaM is represented by $*(\mathrm{p}<0.05)$. The increase in basal activity upon exposure to $5 \mu \mathrm{M}$ PQ compared to control samples was quite significant, ** (p< $0.01)$. The inhibition of PMCA activity ( \pm CaM) following exposure to 50 and $100 \mu \mathrm{M} P Q$ was also highly significant, \# $(\mathrm{p}<0.001)$. 

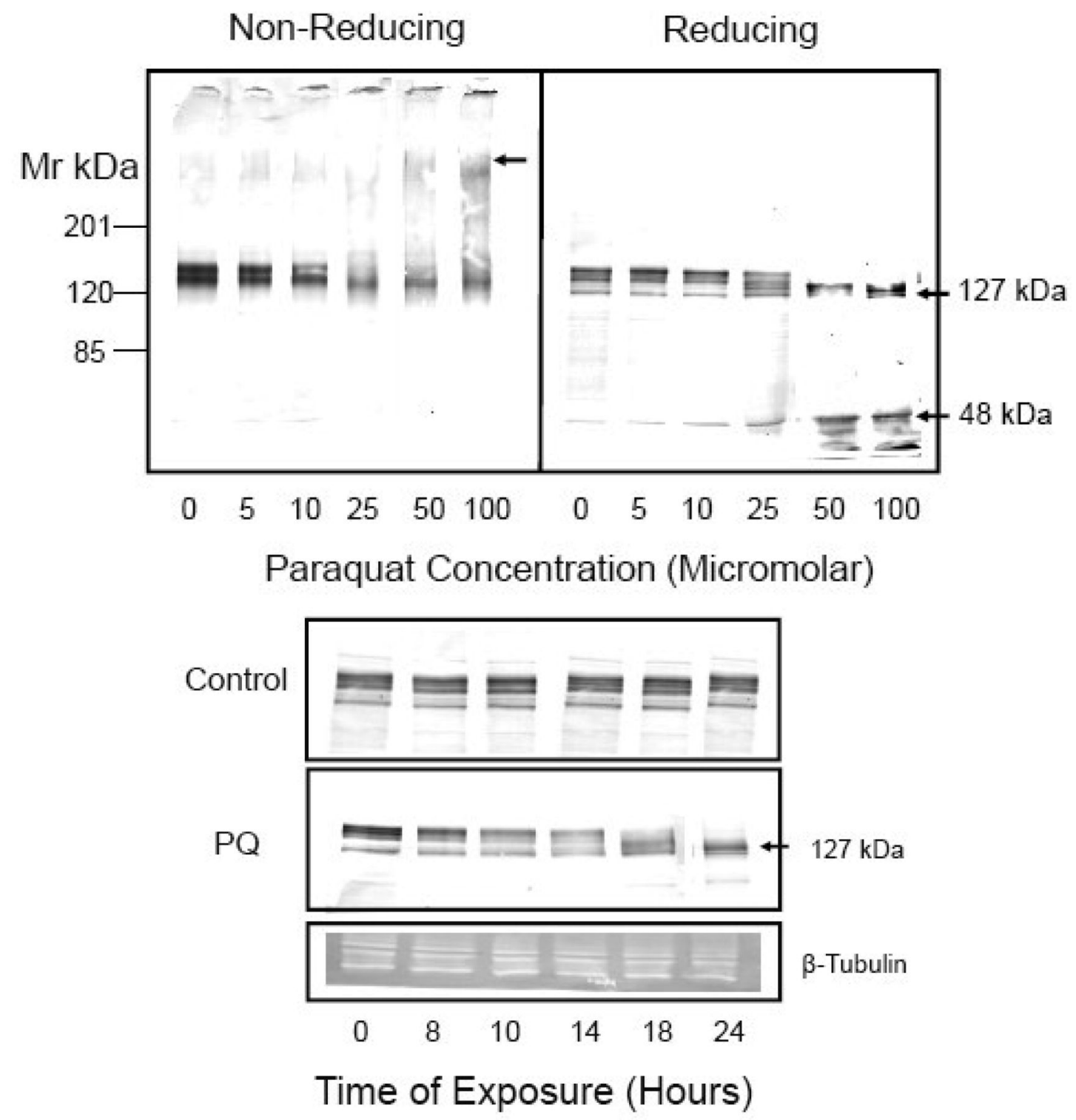

Fig. 4.

Dose and time-dependence of effects of PQ on the electrophoretic mobility of PMCA. (A) Cortical neurons were exposed to the indicated concentrations of $\mathrm{PQ}$ for $24 \mathrm{~h}$ and, following lysis, the particulate fraction obtained after centrifugation at 13,000 $\times \mathrm{g}$ for $15 \mathrm{~min}$ was resuspended in $50 \mathrm{mM}$ Tris-Cl, $\mathrm{pH} 7.4,0.32 \mathrm{M}$ sucrose and $50 \mu \mathrm{M} \mathrm{MgCl} 2$. Ten microgram of protein in the neuronal particulate fraction was separated by SDS-PAGE $(7.5 \%)$ performed under non-reducing conditions (left panel) and under reducing conditions (right panel). Immunoblots were incubated overnight with a pan PMCA antibody (1:1000) and for 2 hours with an alkaline phosphatase-conjugated secondary antibody (1:1000). Representative blots from 5 independent experiments with similar results are shown. (B) Time-dependence of PMCA proteolysis. Neurons were exposed to $50 \mu \mathrm{M}$ PQ for increasing periods of time and immunoblots of the particulate fraction were probed with a pan PMCA antibody as described above. Beta-tubulin was used as a loading control. Representative immunoblots from 3 independent experiments with similar results are shown. 


\section{PMCA 2}
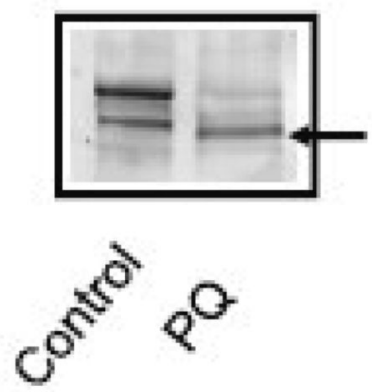

\section{PMCA 4}
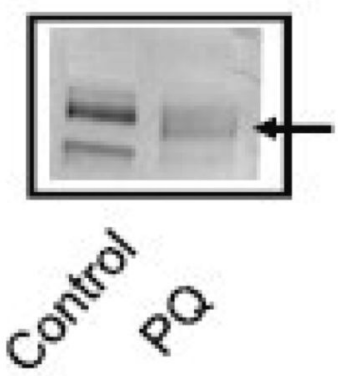

Fig. 5.

Effect of PQ on the electrophoretic mobility of PMCA isoforms. Immunoblot analysis was carried out on the particulate fraction from neurons treated with $50 \mu \mathrm{M}$ PQ for $24 \mathrm{~h}$. Twenty microgram of protein was loaded for PMCA 2 and $50 \mu \mathrm{g}$ of protein for PMCA 4 . Membranes were probed with anti-PMCA 2 and anti-PMCA 4 antibodies (1:400) for $24 \mathrm{~h}$, followed by antirabbit (PMCA 2) or anti-mouse (PMCA 4) alkaline phosphatase-conjugated secondary antibodies. Representative blots from 3 independent experiments with similar results are shown. 


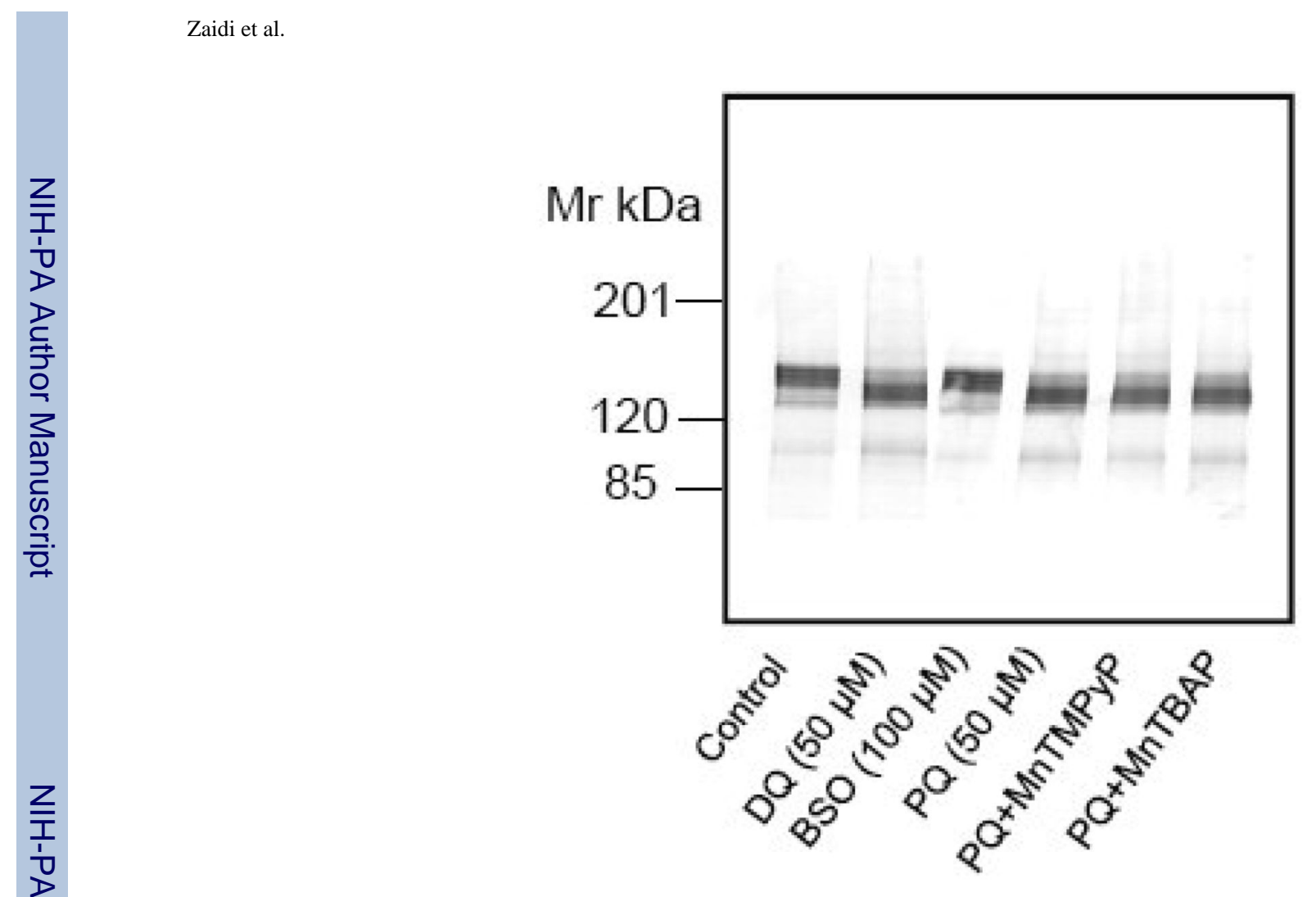




\section{Reducing Non-Reducing}

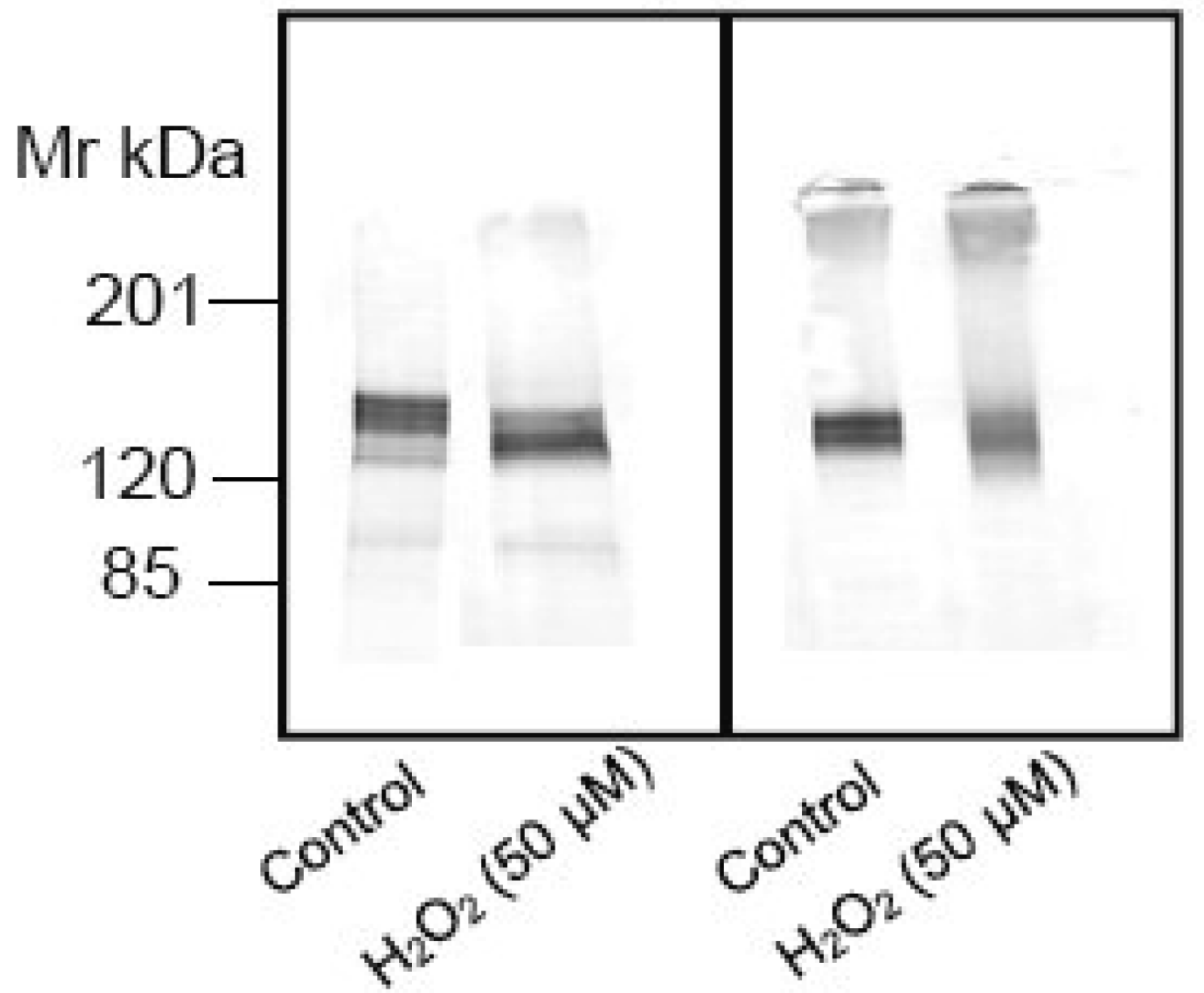

Fig. 6.

Effect of various pharmacological agents and hydrogen peroxide on PMCA. (A) Neurons were exposed to DQ $(50 \mu \mathrm{M})$, BSO $(100 \mu \mathrm{M})$ or PQ $(50 \mu \mathrm{M})$ for 24 h or pretreated for 1 hour with MnTMPyP or MnTBAP $(50 \mu \mathrm{M})$ prior to exposure to PQ. The cells were lysed in $3 \mathrm{mM}$ Tris$\mathrm{HCl}, \mathrm{pH}$ 8.0, and 10 micrograms of protein separated and probed with pan PMCA antibody (1:1000). (B) Neurons were exposed to $\mathrm{H}_{2} \mathrm{O}_{2}(50 \mu \mathrm{M})$ for $18 \mathrm{~h}$, proteins were separated under reducing $v s$ non-reducing conditions, and the membranes probed with the pan PMCA antibody (1:1000). 

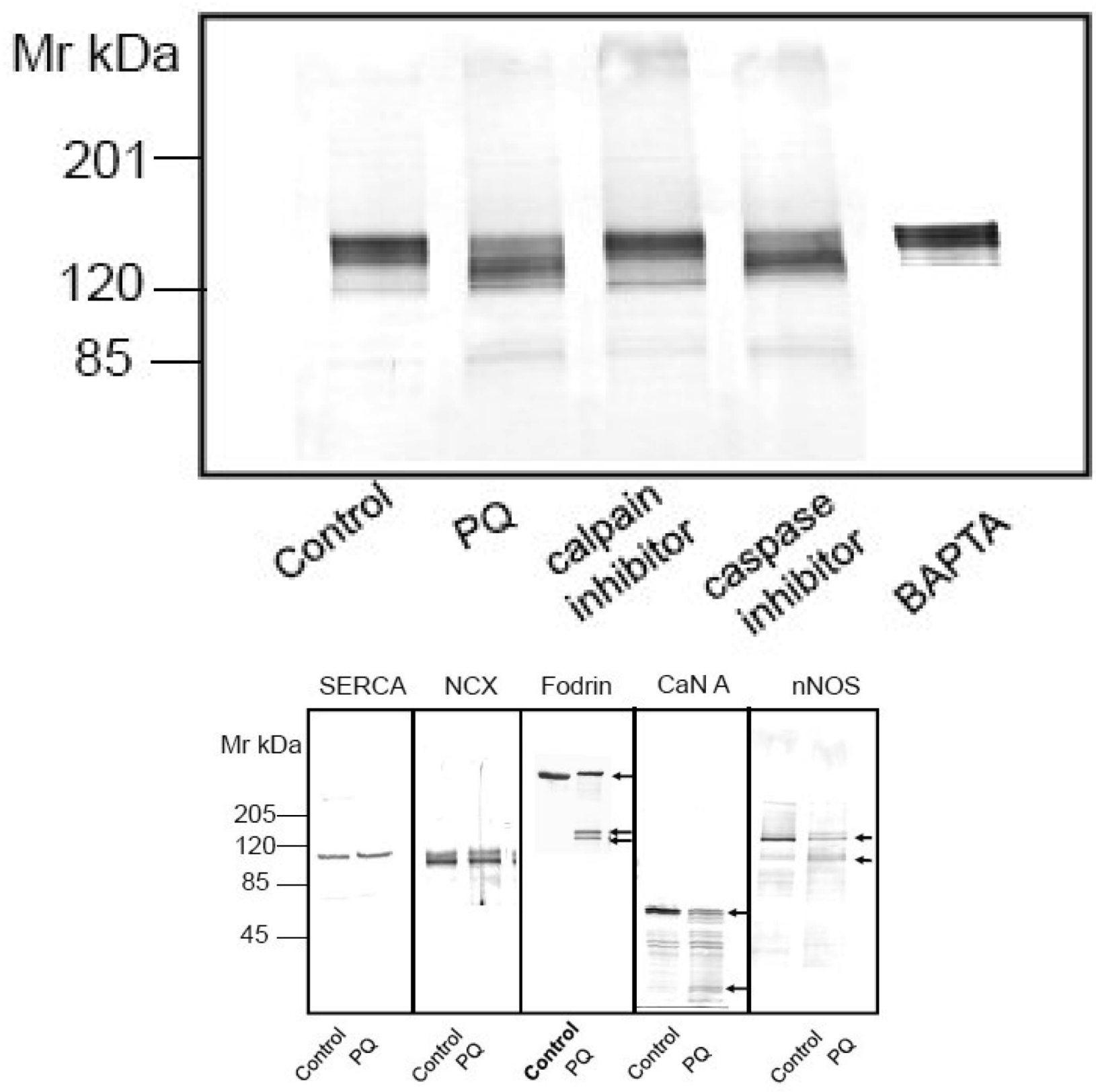

Fig. 7.

Effect of calpain and caspase inhibitors and a $\mathrm{Ca}^{2+}$ - chelating agent on PQ - induced PMCA proteolysis and degradation of other known calpain substrates. (A) Neurons were exposed to $50 \mu \mathrm{M}$ PQ for $24 \mathrm{~h}$ in absence and presence of a calpain specific inhibitor (carbobenzoxy-valylphenylalaninal, $100 \mu \mathrm{M}$ ), or a pan caspase inhibitor (benzyloxycarbonylval-ala-aspfluoromethyl ketone, $100 \mu \mathrm{M}$ ), added to the cell culture media 1h prior to PQ. Chelation of $\left[\mathrm{Ca}^{2+}\right]_{\mathrm{i}}$ was accomplished by replacing the cell culture medium with a $\mathrm{Ca}^{2+}$-free medium and exposing neurons to BAPTA-AM $(50 \mu \mathrm{M})$ for $30 \mathrm{~min}$. Ten microgram of protein from the particulate fraction was immunoblotted and probed with pan PMCA antibody (1:1000). (B) Effect of PQ on other known calpain substrates. Neuronal lysate $(30 \mu \mathrm{g})$ was run on SDSPAGE (4-12\% gradient gel), transferred, and probed with antibodies to two other $\mathrm{Ca}^{2+}$ transporters that are not regulated by CaM, i.e., SERCA (1:500) and NCX (1:500), and to three 
proteins that are regulated by CaM, i.e., $\alpha$-fodrin (1:1000), CaN A (1:500), and nNOS (1:1000). Representative blots from 3 independent experiments with similar results are shown. 